ACTA VET. BRNO 2001, 70: 433-442

\title{
FACTORS AFFECTING MITOGENIC RESPONSE OF TURKEY LYMPHOCYTES
}

\author{
C. C. LOA, T. L. LIN, C. C. WU \\ Department of Veterinary Pathobiology, Purdue University, West Lafayette, Indiana 47907-1175, USA \\ Received May 25, 2001 \\ Accepted October 31, 2001
}

Abstract

Loa C. C., T. L. Lin, C. C. Wu: Factors Affecting Mitogenic Response of Turkey Lymphocytes. Acta Vet. Brno 2001, 70: 433-442.

The objective of the present study was to determine the parameters and conditions for measuring mitogenic response of turkey whole blood and spleen lymphocytes that may be useful in studying cellular immunity of turkeys. Heparinized whole blood or spleen was collected from normal turkeys. The mitogenic assay of whole blood lymphocytes was examined by different combinations of blood dilution $(1: 10$ to $1: 80)$, concanavalin A (Con A) concentration (0 to $320 \mathrm{~g} / \mathrm{ml}$ ), and serum of different species added. The mitogenic assay of spleen lymphocytes was examined by different combinations of spleen cell concentration $\left(1 \times 10^{6}\right.$ to $1 \times 10^{7}$ cells $\left./ \mathrm{ml}\right)$, Con A concentration ( 0 to $25 \mu \mathrm{g} / \mathrm{ml})$, and serum of different species added. The effect of age on the mitogenic response of turkey whole blood cells and spleen cells to Con A was also examined. Both turkey serum and fetal bovine serum enhanced the counts per minute (CPM) readings of the whole blood assay. The presence of fetal bovine serum produced higher stimulation index (SI) than the presence of turkey serum. In the presence of fetal bovine serum, the highest CPM and SI for the whole blood assay were observed with blood dilution at 1:40 and Con A concentration of $40 \mu \mathrm{g} / \mathrm{ml}$. The highest CPM and SI for the spleen cell assay were observed using turkey serum and Con A concentration of $12.5 \mu \mathrm{g} / \mathrm{ml}$. Spleen cell concentrations for the highest CPM were $5 \times 10^{6}$ and $1 \times 10^{7}$ cells $/ \mathrm{ml}$ whereas those for the highest SI were $2.5 \times 10^{6}$ and $5 \times 10^{6}$ cells $/ \mathrm{ml}$. The mitogenic responses of both whole blood assay and spleen cell assay varied among turkeys of different ages. The results indicated that addition of fetal bovine serum is better for the mitogenic response of turkey whole blood lymphocytes and addition of turkey serum is better for the mitogenic response of turkey spleen lymphocytes. In the presence of appropriate serum, the greatest mitogenic response of turkey lymphocyte to Con A could be obtained by checkerboard tests of whole blood dilutions, spleen cell concentration, or Con A concentration.

Blastogenic response, cellular immunity, lymphocyte proliferation assay, mitogenic response, turkey immunity, whole blood cell assay

Lymphocytes from a variety of animal species can be stimulated in vitro to undergo blastogenic transformation and to synthesize DNA upon exposure to plant lectins such as concanavalin A (Con A) of the jack bean, phytohemagglutinin (PHA) of the red kidney bean, or pokeweed mitogen (PWM) of the pokeweed plant. Lectins bind carbohydrate residues of glycoproteins on the surface of lymphocytes and make them proliferate. Not all lymphocytes respond equally to all lectins. Concanavalin A is a T cell specific mitogen (Toivanen and Toivanen 1973). Phytohemagglutinin primarily stimulates T cell proliferation, although it has a slight effect on B cells. Pokeweed mitogen stimulates both T and B cells. The degree of the stimulation can be detected by the incorporation of ${ }^{3} \mathrm{H}$-thymidine into DNA. Although mitogenic response is not a specific effector function of $\mathrm{T}$ lymphocytes, in contrast to cytotoxic activity, mitogenic assay is reliable, simple, and easy to perform and has been used extensively to assess the overall cellular immunocompetence of an animal (Stobo et al. 1972; Nagaraja et al. 1982).

Procedures for avian lymphocyte mitogenic responses using whole blood cells or peripheral blood lymphocytes have been described (Lee 1974; Maheswaran et al. 1975;

Address for correspondence:

T. L. Lin. D.V.M., Ph.D.

Department of Veterinary Pathobiology,

Purdue University 
Lee 1978; Barta et al. 1992; Sharma and Belzer 1992). However, the optimal test conditions for turkey blood cells varied among reports from different laboratories. Maheswaran et al. (1975) indicated that the presence of fetal bovine serum (FBS) or turkey serum (TS) reduced the mitogenic response of turkey buffy coat cells. However, either FBS or TS was recommended for the mitogenic response of turkey buffy coat cells in another report (B arta et al. 1992) and TS was found to be better than FBS, chicken serum (CS), or serum-free for the mitogenic response of turkey whole blood cells (Sharma and Belzer 1992). In addition, checkerboard tests of parameters for mitogenic assay of turkey lymphocytes to Con A using spleen cells have not been reported. The purpose of the present study was to determine the parameters and conditions that may generate meaningful results of mitogenic responses of lymphocytes in turkey whole blood or spleen to Con A.

Turkeys

\section{Materials and Methods}

Day-old turkey poults (British United Turkey of American, BUTA) of both sexes were obtained from Perdue Farm (Washington, IN). They were housed in Horsfall-Bauer isolation units under negative-pressure ventilation for 4 weeks and then transferred to isolated floor pens. Feed and water were provided ad libitum. All animals were maintained and supervised by the Purdue Animal Care and Use Committee (PACUC).

Preparation of whole blood cells

Whole blood samples were obtained by venipuncture from wing vein with a syringe containing heparin at 20 units / $\mathrm{ml}$ of blood. The heparinized blood samples were diluted with RPMI-1640 medium (Gibco BRL, Grand Island, NY) containing $0.25 \mu \mathrm{g} / \mathrm{ml}$ of amphotericin, 100 units / $\mathrm{ml}$ of penicillin, and $100 \mu \mathrm{g} / \mathrm{ml}$ of streptomycin and supplemented with no serum, turkey serum (TS), chicken serum (CS), or fetal bovine serum (FBS) at the dilution factors of $10,20,40$, or 80 .

Preparation of spleen cells

Spleens were removed, suspended in cold Hanks' balanced salts solution (HBSS) buffer, and crushed by a syringe plunger. Tissue debris was removed by passing the spleen suspensions through 100-mesh stainless screen (Sigma, St. Louis, MO) to obtain single spleen cell suspensions. The cell suspensions were washed once with HBSS buffer and red blood cells were lysed with $7.5 \%$ of ammonium chloride solution. Spleen cells were washed again, counted, and resuspended in RPMI-1640 medium (Gibco BRL) containing $0.25 \mu \mathrm{g} / \mathrm{ml}$ of amphotericin, 100 units $/ \mathrm{ml}$ of penicillin, and $100 \mu \mathrm{g} / \mathrm{ml}$ of streptomycin and supplemented with no serum, TS, CS, or FBS to a final concentration of $1 \times 10^{6}, 2.5 \times 10^{6}, 5 \times 10^{6}$, or $1 \times 10^{7}$ cells $/ \mathrm{ml}$.

Concanavalin A

Concanavalin A (Sigma, St. Louis, MO) was diluted with RPMI-1640 medium (Gibco BRL) containing $0.25 \mu \mathrm{g}$ $/ \mathrm{ml}$ of amphotericin, $100 \mathrm{units} / \mathrm{ml}$ of penicillin, and $100 \mu \mathrm{g} / \mathrm{ml}$ of streptomycin and supplemented with no serum, TS, CS, or FBS. The concentrations of Con A are 5, 10, 20, 40, 80, 160, and $320 \mu \mathrm{g} / \mathrm{ml}$ for the whole blood assay and $1.5,3,6,12.5$, and $25 \mu \mathrm{g} / \mathrm{ml}$ for the spleen cell assay.

Mitogenic response of turkey lymphocytes to Con A

One hundred microliters of the adjusted heparinized whole blood cell or spleen cell suspensions were placed in wells of a 96-well microtiter plate. To each well of 3 sequential triplicate cultures in a row were added $100 \mu \mathrm{l}$ of RPMI medium (Gibco BRL) without mitogen or containing different concentrations of Con A. Cell culture were incubated at $40{ }^{\circ} \mathrm{C}$ for $48 \mathrm{~h}$ in a humidified air atmosphere at $5 \% \mathrm{CO}_{2}$ and pulsed with $1 \mu \mathrm{Ci}$ of ${ }^{3} \mathrm{H}$-thymidine in $50 \mu \mathrm{l}$ of RPMI medium (Gibco BRL) containing $0.25 \mu \mathrm{g} / \mathrm{ml}$ of amphotericin, $100 \mathrm{units} / \mathrm{ml}$ of penicillin, and $100 \mu \mathrm{g} / \mathrm{ml}$ of streptomycin and supplemented with the corresponding serum per well for the final $5 \mathrm{~h}$ of incubation. Cells were harvested onto glass filter papers with an automatic cell harvester (Packard, Downers Grove, IL). The counts per minute (CPM) values of individual cell samples were measured in a Packard TopCount Scintillation Counter Model B9904 (Packard). The CPM values of the triplicate cultures within each sample were averaged. Stimulation index (SI) was calculated by dividing the average CPM value in mitogen-stimulated cultures by the average CPM value in unstimulated cultures. Difference (D) of CPM was calculated as the average CPM value in mitogen-stimulated cultures minus the average CPM value in unstimulated cultures.

Experimental design

Experiment 1.

Whole blood samples from 5.5, 6.5, or 9.5 weeks old turkeys were used for establishment of mitogenic assay for turkey whole blood cells. Spleen cells from 2.5, 5.5, or 7.5 weeks old turkeys were used for establishment of mitogenic assay for turkey spleen cells. The influences of dilution of whole blood cells, spleen cell concentration, 
addition of serum of different species, and concentration of Con A on the mitogenic responses of turkey whole blood cells or spleen cells were examined. Combinations of variables for whole blood cell assay included dilution factors of whole blood at 10, 20,40, or 80, inclusion of no serum, TS, CS, or FBS in the culture medium, and concentrations of Con A at $0,5,10,20,40,80,160$, or $320 \mu \mathrm{g} / \mathrm{ml}$. Combinations of variables for spleen cell assay included concentrations of spleen cells at $1 \times 10^{6}, 2 \times 10^{6}, 5 \times 10^{6}$, or $1 \times 10^{7}$ cells / ml, inclusion of no serum, TS, $\mathrm{CS}$, or FBS in the culture medium, and concentrations of Con A at $1.5,3,6,12.5$, or $25 \mu \mathrm{g} / \mathrm{ml}$.

Experiment 2.

Fourty turkeys were used to examine the influence of age of turkeys on the mitogenic responses of whole blood cells or spleen cells. At the ages of $11,13,17,24,31,38,52$, and 73 days, five birds were randomly selected and sacrificed by decapitation. Whole blood cells and spleen cells were collected and the mitogenic assays were carried out under the conditions to obtain the greatest mitogenic response as established in Experiment 1.

Statistical analysis

Calculated means of D and SI from each group were compared by one-way analysis of variance (ANOVA). Significant differences of means between groups were determined at $p<0.05$ (Shoukri and Pause 1999).

\section{Results}

Mitogenic response of turkey lymphocytes to Con A using whole blood cells For mitogenic response of whole blood cells from a 9.5 weeks old turkey, the presence of FBS, TS, or no serum resulted in higher CPM readings than that of CS (Fig. 1). In the presence of FBS, the highest CPM reading of 22,343 (Fig. 1b) and SI of 122 (Fig. 1f) were observed with combination of Con A concentration at $40 \mu \mathrm{g} / \mathrm{ml}$ and blood dilution at 1:40. In the serum-free system, the highest CPM reading of 11,936 (Fig. 1a) and SI of 98 (Fig. 1e) were observed with combination of Con A concentration at $10 \mu \mathrm{g} / \mathrm{ml}$ and blood dilution at 1:20. In the presence of TS, the highest CPM reading of 18,454 was observed with combination of Con A concentration at $40 \mu \mathrm{g} / \mathrm{ml}$ and blood dilution at 1:20 (Fig. 1c). The highest SI of 19 was observed with combination of Con A concentration at $80 \mathrm{~g} / \mathrm{ml}$ and blood dilution at 1:80 (Fig. 1g). Similar results were obtained in experiments with whole blood cells from 5.5 or 6.5 weeks old turkeys (data not shown). Although the conditions to obtain the greatest mitogenic response varied slightly in each experiment, mitogenic responses of turkey lymphocytes to Con A using whole blood cells were the greatest when FBS was used, Con A concentration was 20 or $40 \mu \mathrm{g} / \mathrm{ml}$, and blood dilution was 1:40 (Table 1).

Table 1

Conditions to obtain the greatest mitogenic responses of turkey lymphocytes to Con A using whole blood cells in different trials

\begin{tabular}{|c|c|c|c|c|}
\hline Trials & $\begin{array}{c}\text { Age }^{\mathrm{a}} \\
(\text { weeks old) }\end{array}$ & Serum $^{\mathrm{b}}$ & $\begin{array}{c}\text { Con A } \\
(\mu \mathrm{g} / \mathrm{ml})\end{array}$ & $\begin{array}{c}\text { Blood } \\
\text { dilution }\end{array}$ \\
\hline 1 & 5.5 & FBS & 40 & $1: 40$ \\
2 & 6.5 & FBS & 40 & $1: 40$ \\
3 & 9.5 & FBS & 20 & $1: 40$ \\
\hline
\end{tabular}

a The age of turkeys when blood samples were collected for checkerboard tests.

${ }^{\mathrm{b}}$ Serum of species present in the culture medium. FBS $=$ fetal bovine serum.

Mitogenic response of turkey lymphocytes to Con A using spleen cells

For mitogenic response of spleen cells from a 2.5 weeks old turkey, the presence of TS, CS, or no serum resulted in higher CPM reading and SI than that of FBS (Fig. 2). In the presence of TS, the highest CPM readings were 221,914 or 223,055 with combination of Con A concentration at $12.5 \mu \mathrm{g} / \mathrm{ml}$ and cell concentration at $5 \times 10^{6}$ or $1 \times 10^{7}$ cells $/ \mathrm{ml}$, respectively (Fig. 2c). The highest SI of 124 or 123 were observed with combination of the same Con A concentration and cell concentration at $2.5 \times 10^{6}$ or $5 \times 10^{6}$ cells $/ \mathrm{ml}$, respectively (Fig. 2g). In the presence of CS, the highest CPM reading of 31,175 (Figure 2d) 

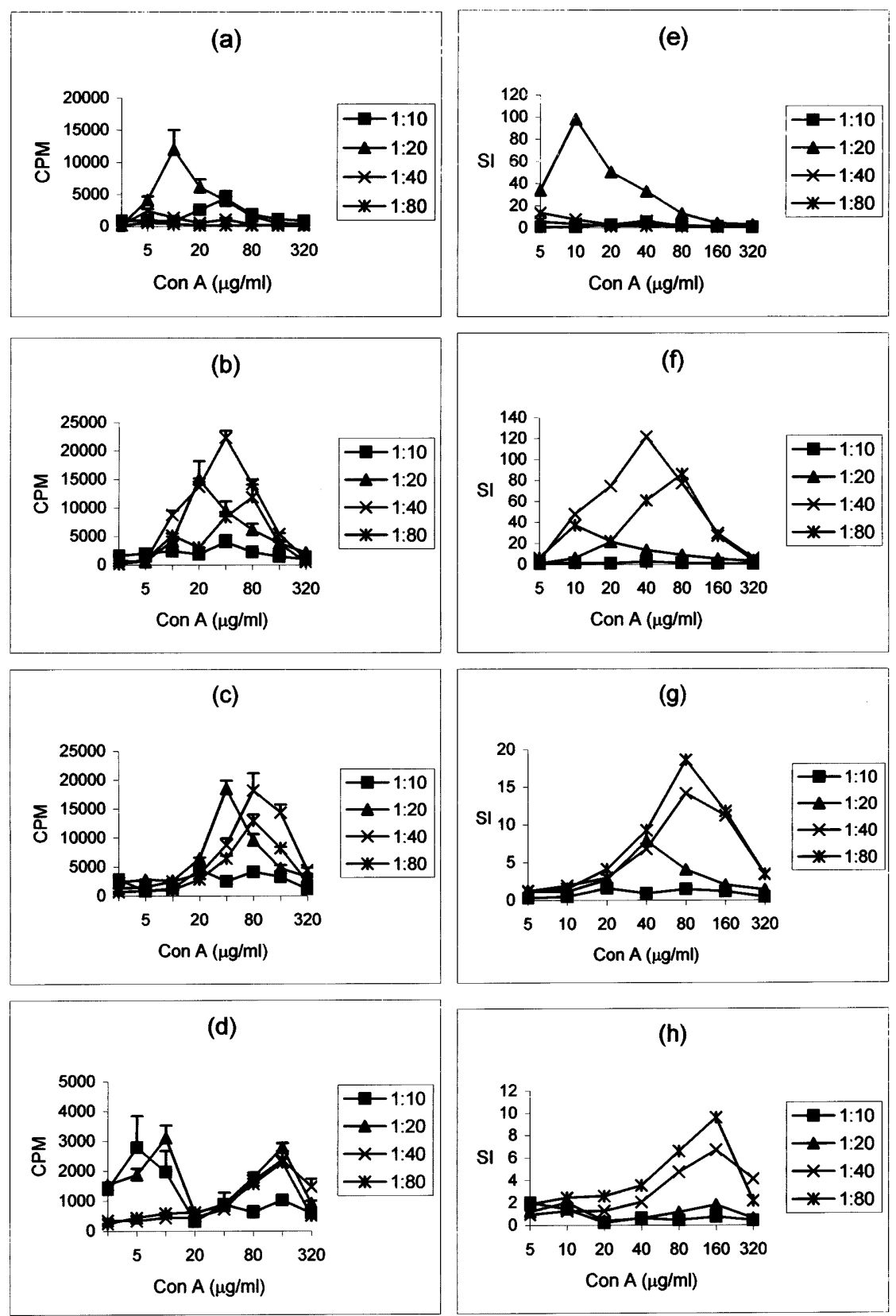

Fig. 1. Optimization of blastogenic assay for turkey whole blood cells to Con A. The in vitro whole blood assay was carried out in a serum-free medium (a and e) or in the presence of fetal bovine serum (b and f), turkey serum (c and $\mathrm{g}$ ), or chicken serum ( $\mathrm{d}$ and $\mathrm{h}$ ). Each line represents a dilution factor of whole blood. The CPM is the mean value of counts per minute from triplicate cultures. The bars represent standard error of the triplicate cultures. The stimulation index (SI) is calculated by dividing the average CPM value of Con A-stimulated cultures by the average CPM value of unstimulated cultures. 
and SI of 28 (Fig. 2h) were observed with combination of Con A concentration at $12.5 \mu \mathrm{g} /$ $\mathrm{ml}$ and cell concentration of $1 \times 10^{7}$ cells $/ \mathrm{ml}$. In the serum-free system, the highest CPM reading of 17,290 was observed with combination of Con A concentration at $1.5 \mu \mathrm{g} / \mathrm{ml}$ and cell concentration at $1 \times 10^{7}$ cells $/ \mathrm{ml}$ (Fig. 2a). The highest SI of 20 was observed with combination of the same Con A concentration and cell concentration at $2.5 \times 10^{6}$ cells $/ \mathrm{ml}$ (Fig. 2e). Similar results were obtained in experiments with spleen cells from 5.5 or 7.5week-old turkeys (data not shown). The greatest mitogenic responses of turkey lymphocytes to Con A using spleen cells were observed when turkey serum was used and cell concentration was $5 \times 10^{6}$ or $1 \times 10^{7}$ cells $/ \mathrm{ml}$. The concentration of Con A to obtain the greatest mitogenic response varied (Table 2).

Table 2

Conditions to obtain the greatest mitogenic responses of turkey lymphocytes to Con A using spleen cells in different trials

\begin{tabular}{|c|c|c|c|c|}
\hline Trials & $\begin{array}{c}\text { Age }^{\mathrm{a}} \\
(\text { weeks old })\end{array}$ & Serum $^{\mathrm{b}}$ & $\begin{array}{c}\text { Con A } \\
(\mu \mathrm{g} / \mathrm{ml})\end{array}$ & $\begin{array}{c}\text { Cell concentration } \\
(\text { cells } / \mathrm{ml})\end{array}$ \\
\hline 1 & 2.5 & TS & 12.5 & $5 \times 10^{6}$ \\
2 & 5.5 & TS & 12.5 & $5 \times 10^{6}$ \\
3 & 7.5 & TS & 1.5 & $5 \times 10^{6}$ \\
\hline
\end{tabular}

a The age of turkeys when spleen cells were collected for checkerboard tests.

${ }^{\mathrm{b}}$ Serum of species present in the culture medium. TS $=$ turkey serum.

Effect of age on mitogenic responses of turkey lymphocytes to Con A

The effect of age on mitogenic responses of turkey lymphocytes to Con A using whole blood cells and spleen cells of turkeys are summarized in Fig. 3. The conditions for whole blood cell assay were addition of FBS in the culture medium, Con A concentration of $40 \mu \mathrm{g}$ / $\mathrm{ml}$, and blood dilution at 1:40. The means of D of whole blood cell assay of 11- and 13day-old groups were significantly higher than that of 38-, 52-, and 73-day-old groups $(p<$ 0.05 ) but not that of 17-, 24-, and 31-day-old groups (Fig. 3a). The mean SI of whole blood cell assay of the 24-day-old group was significantly higher than that of all other age groups $(p<0.05)$ except 13-day-old group (Fig. 3c). The conditions for spleen cell assay were addition of TS in the culture medium, Con A concentration of $12.5 \mu \mathrm{g} / \mathrm{ml}$, and cell concentration of $5 \times 10^{6}$ cells $/ \mathrm{ml}$. The mean of D of spleen cell assay of 11-day-old group was significantly higher than that of all other age groups $(p<0.05)$ (Fig. 3b). The means of $\mathrm{D}$ of 24- and 31-day-old groups were significantly higher than that of 52- and 73-day-old groups. The mean SI of the spleen cell assay of the 24 days old group was significantly higher than that of all other groups $(p<0.05)$ (Fig. 3d). Considerable individual variations in the mitogenic responses of whole blood cells and spleen cells between turkeys of the same age were observed at all age levels tested.

\section{Discussion}

The results of the turkey lymphocyte response to Con A were the sum effect of the three parameters tested: presence of serum in the culture medium, Con A concentration, and whole blood dilution or spleen cell concentration. Under a particular condition of one of these three parameters, the conditions of the other two factors to obtain the greatest mitogenic response varied. For example, in the serum-free system of turkey whole blood cells, the Con A concentration and blood dilution to obtain the greatest mitogenic response were $10 \mu \mathrm{g} / \mathrm{ml}$ and 1:20, respectively. In contrast, in the presence of FBS, the Con A concentration and blood dilution to obtain the greatest mitogenic response were $40 \mu \mathrm{g} / \mathrm{ml}$ and 1:40, 

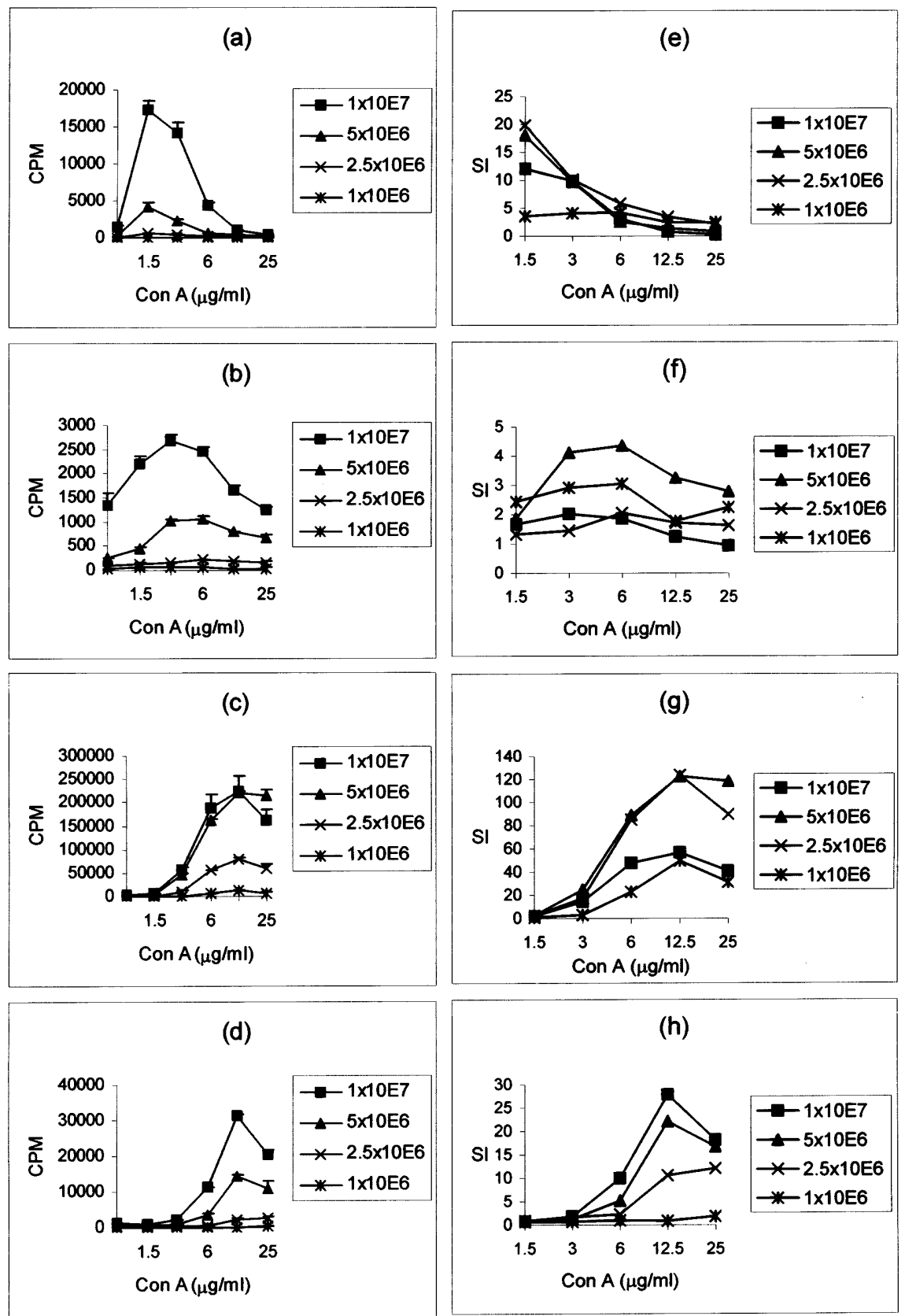

Fig. 2. Optimization of blastogenic assay for turkey spleen cells to Con A. The in vitro spleen cell assay was carried out in a serum-free medium ( $a$ and e) or in the presence of fetal bovine serum ( $b$ and $f$ ), turkey serum (c and $g$ ), or chicken serum $(\mathrm{d}$ and $\mathrm{h}$ ). Each line represents a concentration of spleen cells. The CPM is the mean value of counts per minute from triplicate cultures. The bars represent standard error of the triplicate cultures. The stimulation index (SI) is calculated by dividing the average CPM value of Con A-stimulated cultures by the average CPM value of unstimulated cultures. 

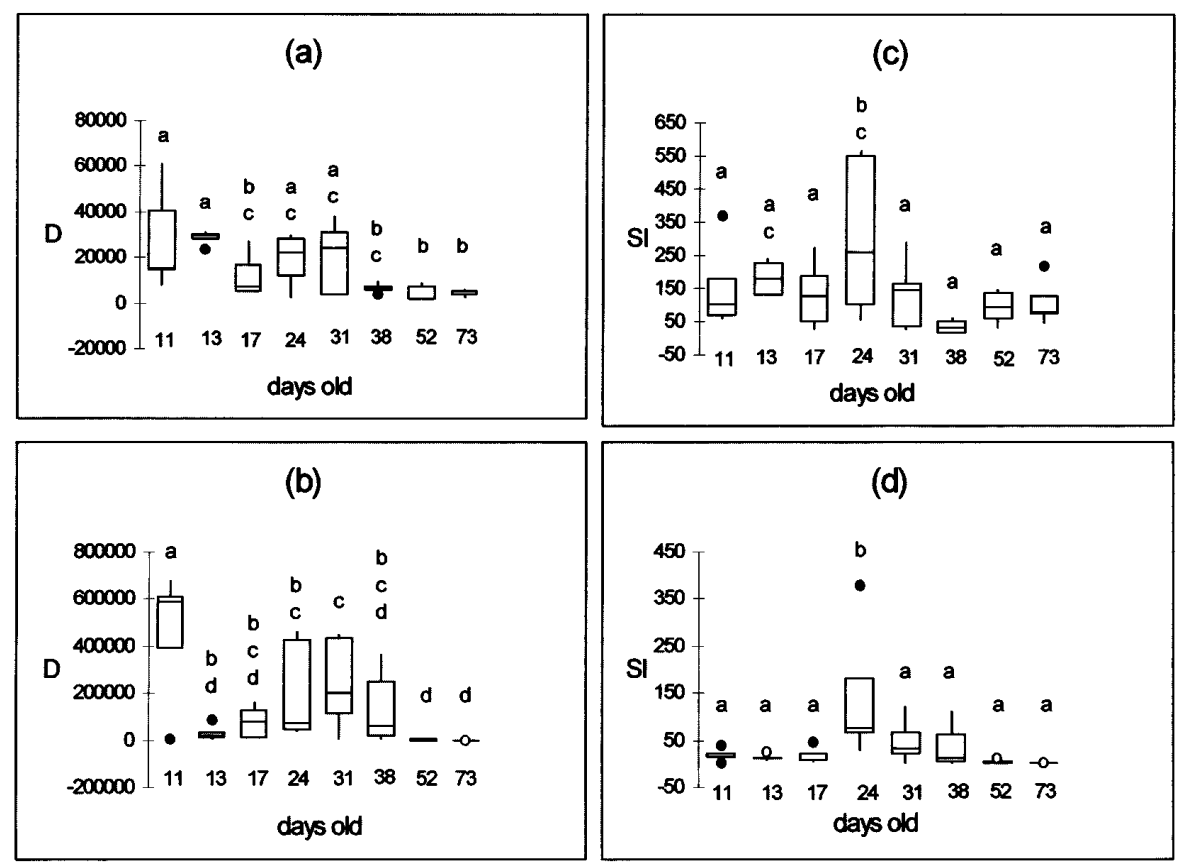

Fig. 3. Boxplot of mitogenic response of whole blood cells (a and c) and spleen cells (b and d) of turkeys at different age levels. The difference (D) of counts per minute (CPM) is calculated as the average CPM value of Con Astimulated cultures minus the average CPM value of unstimulated cultures. The stimulation index (SI) is calculated by dividing the average CPM value of Con A-stimulated cultures by the average CPM value of unstimulated cultures. The box indicates the range between first and third quartile. The line within the box indicates the second quartile (median). The vertical line above or below the box indicates the maximum or minimum data within 1.5 interquartile range (the range within the box) away from the box. The black dot indicates data point in between 1.5 and 3 interquartile range away from the box. The open dot indicates data point more than 3 interquartile range away from the box. The conditions for whole blood cell assay are inclusion of FBS in the culture medium, Con A concentration of $40 \mu \mathrm{g} / \mathrm{ml}$, and blood dilution at 1:40. The conditions for spleen cell assay are inclusion of TS in the culture medium, Con A concentration of $12.5 \mu \mathrm{g} / \mathrm{ml}$, and cell concentration of $5 \times 10^{6}$ cells $/ \mathrm{ml}$. Means of groups within a panel with no common letter differ significantly $(p<0.05)$.

respectively. Therefore, checkerboard tests focusing on a single factor or two factors without consideration of the influence of the other variable(s) may lead to sub-optimal conditions for the mitogenic response of lymphocytes. This probably contributes to the inconsistent results of the published optimal conditions for mitogenic response of turkey lymphocytes as reported from different laboratories (Maheswaran et al. 1975; Barta et al. 1992; Sharma and Belzer 1992; Agrawal and Reynolds, 1999). Selection of the conditions to obtain the greatest mitogenic response according to CPM reading or SI also gave different results. For example, cell concentration at $1 \times 10^{7}$ cells $/ \mathrm{ml}$ produced the highest $\mathrm{CPM}$ reading of mitogenic responses of turkey spleen cells when TS was in the medium and Con A concentration was $12.5 \mu \mathrm{g} / \mathrm{ml}$. However, the SI of the same condition was lower than that of cell concentration at $2.5 \times 10^{6}$ or $5 \times 10^{6}$ cells $/ \mathrm{ml}$. Therefore, the conditions to obtain the greatest mitogenic response for each variable could be different based on CPM readings or SI. In comparison, Sharma and Belzer (1992) optimized the assay based on CPM reading. Barta et al. (1992) as well as Agrawal and Reynolds (1999) selected the optimal conditions according to SI. In the study of Mahes waran et al. (1975), both CPM 
reading and SI were used. In their study, the level of CPM reading was in line with that of SI. However, this was not always the case in the present study.

The observation of higher CPM readings of whole blood assay in the presence of FBS or TS was in line with the recommendation of Barta et al. (1992). Sharma and Belzer (1992) demonstrated that presence of TS but not FBS enhanced the CPM readings of the mitogenic response of turkey whole blood cells. This is not in full agreement with the results of the present study that both TS and FBS enhanced the CPM readings of the whole blood assay. In fact, the presence of FBS gave higher SI in the mitogenic assay of turkey whole blood cells than the presence of TS in the present study. This was caused by higher background CPM readings of unstimulated whole blood cultures in the presence of TS. The finding of high CPM readings and SI of whole blood assay in the serum-free system was comparable with the report of Mahes waran et al. (1975). However, the presence of FBS always produces higher CPM readings and SI in the mitogenic assay of turkey whole blood cells than the serum-free system in three experiments in the present study. Therefore, it is recommended to use FBS in the mitogenic assay of turkey whole blood cells.

The presence of TS produced higher CPM readings and SI in the mitogenic assay of turkey spleen cells than the presence of FBS. The discrepancy of favored serum in the mitogenic assays of whole blood cells and spleen cells may be due to the presence of turkey serum, as an original component of the blood, in the whole blood assay. According to the observation that the presence of TS gave high background CPM readings of unstimulated whole blood cultures, TS is probably important for supporting in vitro culture of turkey lymphocytes. In the absence of TS, lymphocytes in the spleen cell assay could not grow well and was not in good condition for the mitogenic assay. Therefore, TS is better than FBS in the spleen cell assay. In the whole blood cell assay, addition of extra TS well supported the cultured blood cells and resulted in higher background CPM readings of unstimulated whole blood cultures. The higher background CPM readings contributed to the lower SI as compared with the presence of FBS, although both TS and FBS produced similar CPM readings in the whole blood cell assay.

The Con A concentration, blood dilution in the whole blood assay, or cell concentration to obtain the greatest mitogenic response in the spleen cell assay varied with the presence of sera of different species. Based on the presence of FBS in the whole blood assay as discussed above, the conditions to obtain the greatest mitogenic response for the whole blood assay were recommended as Con A concentration of $40 \mu \mathrm{g} / \mathrm{ml}$ and blood dilution at 1:40. In the presence of TS, Con A concentration of $12.5 \mathrm{~g} / \mathrm{ml}$ and cell concentration at $5 \times 10^{6}$ cells / $\mathrm{ml}$ were recommended for the spleen cell assay. In choosing the dilution factor of blood, the filters of cell harvester easily got clogged with clumps of erythrocytes during the harvest of cells when the dilution factor was less than 1:20.

The observation that the concentration of Con A to obtain the greatest mitogenic response varied in different experiments with cells from different birds was in accordance with that of previous reports (Barta et al. 1992; Sharma and Belzer 1992). For whole blood assay, this variation was suspected to be caused by considerable variation in the number of lymphocytes in blood samples at the time of sample collection from different birds. However, this can not explain the similar phenomenon in the spleen cell assay where the cell number in each well was the same in each experiment. The variation in the level of mitogenic responses between individual birds may be resulted from the genetic diversity. The ability of chicken lymphocytes to respond to Con A was under genetic control (Miggiano et al. 1976). Lymphocytes from chickens with genetic difference had different proliferative response to Con A. In addition, the genetic selection of turkeys for increased body weight or egg production affected the mitogenic responses of turkey lymphocytes to Con A (B ay y ari et al. 1997; Li et al. 1999). The turkeys in the present study were obtained from commercial turkey flocks originating from outbred breeder stocks and had diverse genetic 
backgrounds. Similar mechanism(s) of genetic control as demonstrated for chicken lymphocytes may also contribute to the observed individual variation in the level of mitogenic responsiveness in these turkeys.

The fluctuation phenomenon of the effect of age on the mitogenic responsiveness of turkey whole blood assay was ever reported before (Sharma and Belzer 1992; Agrawal and Reynolds 1999). Similar phenomenon of the effect of age was also observed on the turkey whole blood assay as well as the spleen cell assay in the present study. Due to the observations of the same phenomenon in different laboratories independently, the possibility of experimental error is probably not the case. The diverse genetic backgrounds of the turkeys may be responsible, at least in part, for the observation. In addition, the nature of the variation of cellular immunity in turkeys at different age is not clear at the present time.

Lymphocytes from blood or spleen compose of a diverse population of cells that participate in a number of immune functions. In vitro mitogenic assay is often used to evaluate the cellular immune competence. As discussed above, many variables are present in the mitogenic assay that may influence the final results. Although it had been suggested that it is not possible to standardize the conditions (Barta et al. 1992), our results recommend using FBS in the turkey whole blood assay and TS in the spleen cell assay. In the presence of appropriate serum, the blood dilution factor or the spleen cell concentration and the Con A concentration to obtain the greatest mitogenic response could be obtained by checkerboard tests.

\section{Faktory ovlivňující mitogenní aktivitu krůtích lymfocytů}

Cílem předkládané studie bylo určit optimální parametry a podmínky pro měření mitogenní aktivity krůtích lymfocytů získaných z plné krve a sleziny, což by bylo možné dále využít při studiu celulární imunity krůt. Zdravým krůtám byla odebrána plná krev, ošetřená heparinem a slezina. Pro test mitogenní aktivity lymfocytů, získaných z plné krve, bylo použito různých kombinací ředění krve (1:10 až 1:80), concavalinu A (Con A) v koncentracích $0-320 \mu \mathrm{g} / \mathrm{ml}$ a sér pocházejících z různých druhů zvírat. $\mathrm{V}$ testu se slezinnými lymfocyty byly analyzovány kombinace různých koncentrací slezinných buněk $\left(1 \times 10^{6}\right.$ až $1 \times 10^{7}$ buněk/ml $)$ s koncentracemi Con $\mathrm{A} v$ rozmezí $0-25 \mu \mathrm{g} / \mathrm{ml}$ a se séry různých živočišných druhů. Rovněž byla sledována mitogenní aktivita krůtích buněk získaných z plné krve a ze sleziny ke Con A v závislosti na věku zviŕat. Bylo zjištěno, že jak krůtí sérum, tak i fetální bovinní sérum zvyšovalo počty odečítaných buněk za minutu (CPM) pocházejících z plné krve. Přítomnost fetálního bovinního séra měla za následek, narozdíl od krůtího séra, vyšší stimulační index (SI). Použití fetálního bovinního séra vykazovalo nejvyšší hodnoty CPM i SI v plné krvi ředěné 1:40 a při koncentraci Con A $40 \mu \mathrm{g} / \mathrm{ml}$. Nejvyšší hodnoty CPM a SI u slezinných buněk byly pozorovány při testování krůtího séra a při koncentraci Con A $12.5 \mu \mathrm{g} / \mathrm{ml}$. Nejvyšších hodnot CPM bylo dosaženo při koncentraci slezinných buněk $5 \times 10^{6}$ a $1 \times 10^{7}$, zatímco nejvyšší hodnoty SI byly pozorovány při koncentracích $2.5 \times 10^{6}$ a $5 \times 10^{6}$ buněk $/ \mathrm{ml}$. Mitogenní aktivita buněk získaných z plné krve a ze sleziny se u krůt lišila i v závislosti na jejich věku. Z uvedených výsledků je zřejmé, že přidáním fetálního bovinního séra dochází ke zvyšování mitogenní aktivity krůtích krevních lymfocytů a že použitím krůtího séra lze zase získat vyšší mitogenní aktivitu krůtích slezinných lymfocytů. Provedením panelových testů s různými ředěními plné krve, s různými koncentracemi slezinných buněk a Con A a současně využitím př́islušného séra lze obdržet nejvyšší hodnoty mitogenní aktivity krůtích lymfocytů ke Con A.

\section{Acknowledgements}

The authors thank the support provided by the Commission of Agriculture, State of Indiana, Pfizer Animal Health, and North Carolina Turkey Spiking Mortality Task Force, and U. S. Dept. of Agriculture. 


\section{References}

AGRAWAL, P. K., REYNOLDS, D. L. 1999: A comparative analysis of the mitogenic response of intestinal intraepithelial lymphocytes in various age groups of turkeys. Avian Dis. 43: 376-383

BARTA, O., BARTA, V., DOMERMUTH, C. H., PIERSON, F. W. 1992: Optimum conditions for the turkey lymphocyte transformation test. Avian Dis. 36: 386-394

BAYYARI, G. R., HUFF, W. E., RATH, N. C., BALOG, J. M., NEWBERRY, L. A., VILLINES, J. D., SKEELES, J. K., ANTHONY, N. B., NESTOR, K. E. 1997: Effect of the genetic selection of turkeys for increased body weight and egg production on immune and physiological responses. Poultry Sci. 76: 289-296

LEE, L. F. 1974: In vitro assay of mitogen stimulation of avian peripheral lymphocytes. Avian Dis. 18: 602-609

LEE, L. F. 1978: Chicken lymphocyte stimulation by mitogen: a microassay with whole-blood cultures. Avian Dis. 22: $296-307$

LI, Z., NESTOR, K. E., SAIF, Y. M., BACON, W. L., ANDERSON, J. W. 1999: Effect of selection for increased body weight on mitogenic responses in turkeys. Poultry Sci. 78: 1532-1535

MAHESWARAN, S. K., THIES, E. S., GREIMANN, C. 1975: A micromethod for evaluating turkey lymphocyte responses to phytomitogens. Am. J. Vet. Res. 36: 1397-1400

MIGGINO, V., NORTH, M., BUDER, A., PINK, J. R. L. 1976: Genetic control of the response of chicken leukocytes to a T-cell mitogen. Nature 263: 61-63

NAGARAJA, K. V., PATEL, B. L., EMERY, D. A., POMEROY, B. S., NEWMAN, J A. 1982: In vitro depression of the mitogenic response of lymphocytes from turkeys infected with hemorrhagic enteritis virus. Am. J. Vet. Res. 43: 134-136

SHARMA, J. M., BELZER, S. W. 1992: Blastogenic response of whole blood cells of turkeys to a T-cell mitogen. Develop. Comp. Immunol. 16: 77-84

SHOUKRI, M. M., PAUSE, C. A. 1999: Statistical methods for health sciences. $2^{\text {nd }}$ ed. CRC press LLC, Boca Raton, Florida.

STOBO, J. D., ROSENTHAL, A. S., PAUL, W. E. 1972: Functional heterogeneity of murine lymphoid cells. 1. Responsiveness to and surface binding of concanavalin A and phytohemagglutinin. J. Immunol. 108: 1-17

TOIVANEN, P., TOIVANEN, A. 1973: Selective activation of chicken T lymphocytes by concanavalin A. J. Immunol. 111: 1602-1606 